Int. J. Electrochem. Sci., 16 (2021) Article ID: 210539

International Journal of

ELECTROCHEMICAL

SCIENCE

www.electrochemsci.org

\title{
COD and Color Removal from Landfill Leachate by photo- electro-Fenton Process
}

\author{
Nevzat Beyaztt ${ }^{1, *}$, Kasim Atmaca ${ }^{2}$ \\ ${ }^{1}$ Department of Environmental Engineering, Ondokuz Mayıs University, Turkey \\ ${ }^{2}$ Department of Environmental Engineering, Ondokuz Mayis University, Turkey \\ *E-mail: nbeyazit@omu.edu.tr
}

doi: $10.20964 / 2021.05 .65$

Received: 15 January 2021 / Accepted: 12 March 2021 / Published: 31 March 2021

This study investigated the effects of operational parameters such as $\mathrm{pH}$ (2.5-5.0), current density (10$\left.50 \mathrm{~A} / \mathrm{m}^{2}\right), \mathrm{H}_{2} \mathrm{O}_{2}$ concentration $(250-1500 \mathrm{mg} / \mathrm{L})$ and distance between electrodes $(1.0-1.5 \mathrm{~cm})$ on COD and color removal from the leachate by the photo-electro-Fenton method. Under determined optimum experimental conditions ( $\mathrm{pH}: 3$, current density: $10 \mathrm{~A} / \mathrm{m}^{2}, \mathrm{H}_{2} \mathrm{O}_{2}: 1000 \mathrm{mg} / \mathrm{L}$, UV lamp: 16W, stirring rate: $250 \mathrm{rpm}$, distance between electrodes: $1.0 \mathrm{~cm}$ ), maximum $83.84 \%$ COD removal and $84.46 \%$ color removal from leachate were achieved with an electrical energy consumption of 11.02 and $5.51 \mathrm{kWh} / \mathrm{m}^{3}$, respectively. Maximum removal efficiencies for COD and color were reached after 90 and 45 minutes of treatment, respectively.

Keywords: COD, color, removal, photo-electro-Fenton, leachate, cost.

\section{$\underline{\text { FULL TEXT }}$}

(C) 2021 The Authors. Published by ESG (www.electrochemsci.org). This article is an open access article distributed under the terms and conditions of the Creative Commons Attribution license (http://creativecommons.org/licenses/by/4.0/). 